\title{
Pengembalian fungsi pengunyahan pada anak dengan kelainan cerebral palsy dan mild mental retardation
}

\author{
Muh. Harun Achmad \\ Peserta Pendidikan Dokter Gigi Spesialis \\ Bagian Ilmu Kedokteran Gigi Anak \\ Fakultas Kedokteran Gigi Universitas Padjajaran \\ Bandung, Indonesia
}

\begin{abstract}
Cerebral palsy is the condition marked by paralysis, weakness, inability coordination or other deviation of motoric function, especially muscles. While mental retardation is development disturbance especially in functions and the intellectual capacity. From the dentistry point of view, the paient had many disturbances because the decreasing of the capacity, include maintenance of the oral dental health. In fact, the requirements in oral and dental health care were not different from other patients, but the implementation usually difficult. Dental care was influenced by several points, psychology, physical, and emotion. The aim of this case study is to report considerations in caring inpatient, improving the chewing function and esthetics and increased patient's self confidence. This case represents a 17 years old man with the cerebral palsy and mild mental retardation, came to the Teeth and Mouth Clinic of YPAC Jakarta to make denture. He complained his chewing abilitiy, and appearance because disturbanced and decreased his self-confidence. In this case, the patient was made frame denture to the teeth 41 to 45, because the ridge had been lost as a result of losing teeth many years ago.after the therapy, it can be concluded that the difficulty in handling the special need children patient could be overcome if the dentist studied the characteristics of the manifestation of his physical and psychological situation of the public well. Professionally a dentist could determine the attitude before planning an operational action on a sufferer.
\end{abstract}

Key word: Cerebral palsy, mental retardation, frame denture

\begin{abstract}
ABSTRAK
Cerebral palsy merupakan suatu kondisi yang ditandai dengan kelumpuhan, kelemahan, ketidakmampuan mengoordinasi atau penyimpangan lainnya dari fungsi motoris, terutama pergerakan otot-otot. Sedangkan Retardasi mental merupakan keterbelakangan terutama dalam fungsi-fungsi dan kemampuan intelektual karena gangguan pada saat perkembangannya. Dari sudut pandang kedokteran gigi, penderita mempunyai banyak hambatan karena kurangnya kemampuan, termasuk sewaktu merawat kesehatan giginya. Kebutuhan perawatan gigi pada penderita tidak banyak berbeda dari perawatan penderita lainnya, tetapi pelaksanaan perawatan biasanya lebih sulit. pelaksanaan perawatan gigi dipengaruhi oleh beberapa masalah mental, fisik, dan emosi. Tujuan studi kasus ini adalah untuk melaporkan perawatan gigi pada pasien untuk memperbaiki fungsi pengunyahan dan penampilan sehingga dapat mengembalikan rasa percaya diri penderita. Seorang pasien laki-laki, umur 17 tahun dengan kelainan cerebral palsy dengan mild mental retardation datang ke klinik Gigi dan mulut YPAC Jakarta. Pasien ingin dibuatkan gigitiruan karena gangguan fungsi pengunyahan serta penampilan yang menyebabkan kurangnya percaya diri pasien. Pasien dibuatkan frame denture pada regio 41 sampai 45, karena pertimbangan lingir yang sudah hilang akibat kehilangan gigi yang terlalu lama. Setelah perawatan, dapat disimpulkan bahwa pasien anak yang berkebutuhan khusus dapat ditangani jika dokter gigi lebih mempelajari sifat umum, manifestasi, keadaan fisik, dan psikologisnya.
\end{abstract}


Secara profesional seorang dokter gigi dapat menentukan sikap sebelum merencanakan suatu tindakan operasi terhadap seorang penderita.

Kata kunci : Cerebral palsy, retardasi mental, frame denture

Koresponden: Edy Machmud, Bagian Prostodonsia, Fakultas Kedokteran Gigi Universitas Hasanuddin, Jl. Kandea No.5 Makassar, Indonesia.

\section{PENDAHULUAN}

Perawatan gigi dan mulut terhadap anak yang mempunyai kebutuhan khusus (special need) seperti cerebral palsy maupun retardasi mental tidak hanya terbatas pada hal-hal yang darurat saja seperti pencabutan gigi, namun mereka perlu juga memperoleh rehabilitasi yang menyeluruh agar gigi dan mulut mereka dapat berfungsi dengan baik, seperti pembuatan gigitiruan pada kehilangan gigi dengan tujuan untuk mengembalikan fungsi pengunyahan serta fungsi estetisnya. $^{1,2}$

Berbagai kelainan yang sering ditemukan pada penderita anak yang berkebutuhan khusus, seperti keadaan retardasi mental dan cerebral palsy, misalnya pada kasus ini juga sering disertai kelainan pada dentokraniofasial dan ototnya. Kelainan tersebut akan menimbulkan masalah dalam kesehatan gigi dan mulutnya, seperti kesulitan untuk menjaga kesehatan gigi dan mulut secara mandiri, kekurangaktifan otot mulut untuk dapat melakukan self cleansing yang baik, dan keadaan maloklusi yang cukup berat. ${ }^{1,2}$

Kesulitan dalam menangani pasien anak yang berkebutuhan khusus dapat diatasi jika dokter gigi dapat mempelajari sifat umum serta manifestasi keadaan fisik dan psikologisnya. Akan tetapi untuk bekerja secara profesional seorang dokter gigi dapat menentukan sikap sebelum merencanakan suatu tindakan terhadap seorang penderita. Jika terdapat suatu kendala, perlu kiranya dirujuk ke dokter gigi yang memiliki sarana yang lebih lengkap dan keahlian tersendiri dalam menangani anak. Akan tetapi jika didapatkan suatu kasus kedaruratan, maka dokter gigi umum sebaiknya dapat melakukan tindakan emergensi dan preventif. ${ }^{1}$

Perawatan gigi dan mulut pada penderita anak yang berkebutuhan khusus perlu mendapat perhatian yang lebih oleh karena hal ini merupakan tanggung jawab profesi kedokteran gigi. Oleh karena itu setiap dokter gigi sudah seharusnya dapat memberikan pelayanan kesehatan gigi dan mulut secara layak bagi setiap penderita anak yang berkebutuhan khusus. Akan tetapi hal di atas harus dapat ditunjang oleh pengetahuan yang cukup, keahlian, ketrampilan serta kemampuan dalam menangani setiap pasien tersebut, serta mengetahui penyebab dan latar belakang keadaan anak yangberkebutuhan khusus tersebut. ${ }^{2,3}$

\section{Cerebral palsy}

Cerebral palsy dapat ditandai dengan adanya kerusakan motorik yang disertai kelainan fungsi tubuh dan mental. Pada tahun 2001 United Cerebral Palsy Foundation memperkirakan bahwa 764.000 anak dan orang dewasa di Amerika Serikat menderita cerebral palsy. ${ }^{3-5}$

Adanya cerebral palsy dapat menimbulkan kelainan fungsi tubuh secara fisik dan mental yang menyeluruh atau gangguan-gangguan pada gaya berjalan, pengamatan, pertumbuhan, atau sensasi. Cerebral palsy adalah cacat yang umum ditemukan pada anak-anak dan menyerang 2 hingga 25 anak per 1.000 kelahiran di Amerika 
Serikat. Diagnosis banding dari cerebral palsy meliputi penyakit metabolisme dan genetik. Tujuan dari perawatan penderita cerebral palsy adalah untuk memperbaiki fungsi dan meningkatkan kemampuan umum penderita untuk dapat mandiri. Kesulitan-kesulitan yang timbul pada penderita cerebral palsy meliputi kejangkejang dan pemendekan otot, kesulitan pada saat makan, drooling, kesulitan dalam berkomunikasi, osteopenia, osteoporosis, fraktur, nyeri, fungsi abnormal pada saluran pencernaan, muntahmuntah, dan konstipasi. ${ }^{4,5}$

\section{Etiologi}

Cerebral Palsy adalah suatu gangguan kondisi neurologi karena kerusakan otak yang terjadi sebelum perkembangan otak sempurna. Karena perkembangan otak terus berlanjut selama dua tahun pertama kehidupan, cerebral palsy dapat diakibatkan oleh kerusakan otak yang terjadi pada periode prenatal, perinatal, atau postnatal. Sebanyak 70-80\% kasus cerebral palsy diperoleh pada saat prenatal dengan penyebab yang tidak diketahui. Komplikasi-komplikasi pada saat kelahiran yang meliputi asfiksia diperkirakan terjadi pada sekitar 6\% pasien dengan cerebral palsy kongenital. Faktor risiko bayi neonatal dengan bayi cerebral palsy meliputi kelahiran di bawah usia kehamilan 32 minggu, berat badan di bawah 2.500 gr, keterlambatan pertumbuhan intrauterine, perdarahan intrakranial, dan trauma. Pada $10-20 \%$ penderita cerebral palsy yang didapat pada saat postnatal, sebagian besar kerusakan otak terjadi karena bakteri meningitis, virus encefalitis, hiperbilirubinemia, benturan pada kecelakaan, terjatuh, atau penyiksaan anak.

\section{Diagnosis}

Perkembangan motorik yang terlambat, tonus otot yang abnormal, dan postur tubuh yang tidak biasa merupakan ciri-ciri dari cerebral palsy. Penilaian gerak refleks penting dilakukan pada masa kanak-kanak. Pada bayi yang tidak mengalami cerebral palsy, refleks Moro jarang terjadi setelah umur 6 bulan, dan refleks gerak tangan jarang berkembang sebelum usia 12 bulan. Refleks gerak tangan bisa muncul sebelum umur 12 bulan pada pasien dengan spastic hemiplegia. Penyakit saraf dan metabolisme yang diturunkan secara bertahap harus disingkirkan sebagai penyebab kelainan. Cara mengetahui cerebral palsy berdasarkan pada gambaran klinis, pola perkembangan gejala, riwayat keluarga, dan faktor-faktor lain yang mempengaruhi kemungkinan diagnosis yang lebih spesifik. Tes laboratorium dan imaging cerebral menggunakan tomografi komputer, magnetic resonance imaging, dan ultrasonik adalah alat-alat yang digunakan untuk fisik diagnotik. Pengamatan untuk kecacatan yang berhubungan seperti cacat pendengaran dan penglihatan, kejang-kejang, masalah pada sensasi rasa dan nyeri, dan gangguan kesadaran dapat membantu untuk melengkapi penilaian dan menegakkan diagnosis. $^{4,5}$

\section{Gejala klinis}

Sebanyak 70-80\% pasien dengan cerebral palsy memiliki gejala klinis kejang. Tangan dan kaki yang terserang memperlihatkan peningkatan refleks tendon yang dalam tremor, hipertonisitas otot, kelemahan, dan ciri khas cara berjalan yang menyilang. ${ }^{3-5}$

Beberapa hal yang perlu diketahui dokter gigi dalam menangani penderita cerebral palsy adalahmempertimbangkan pengobatan penderita dengan gerakan terbatas pada kursi roda, bentuk pemindahan pilihan jika akan dipindahkan dari kursi roda, usahakan untuk menstabilkan kepala penderita pada semua tahap dari pengobatan gigi, 
menempatkan dan mempertahankan penderita pada posisi tegap di kursi gigi dengan tangan dan kaki sebagai penopang tubuh agar dapat dikerjakan dengan mudah, memposisikan punggung penderita sedikit lebih tinggi untuk memperkecil kesulitan menelan, penempatan penderita pada kursi gigi disesuaikan dengan posisi dari tangan dan kaki tidak melawan anggota badan. Untuk itu pertimbangkan penggunaan bantal, handuk dan tindakan lainnya untuk mendukung tubuh dan anggota geraknya. Selanjutnya hal lain yang harus diperhatikan adalah menggunakan pengendalian fisik secara bijaksana untuk mengontrol gerakan dari anggota ekstremitas, mengontrol gerakan rahang yang tidak terkendali pilih dari bermacam-macam mouth props dan split finger, memperkecil refleks kaget, hindari rangsangan yang berupa gerakan tiba-tiba, keributan, dan cahaya tanpa peringatan terlebih dahulu, pengenalan rangsang dalam mulut secara lambat, untuk menghindari refleks muntah, pertimbangkan untuk menggunakan rubber dam untuk prosedur restorasi gigi, dan bekerja secara efisien dan efektif waktu penderita di kursi untuk menekan kelemahan otot. ${ }^{4-6}$

\section{Retardasi mental}

Retardasi mental adalah suatu kondisi yang ditandai oleh intelegensi di bawah normal, disertai kendala dalam penyesuaian perilaku. Gejala tersebut timbul pada masa perkembangan yaitu di bawah usia 18 tahun. Sedangkan retardasi mental menurut WHO adalah kemampuan mental yang tidak mencukupi. ${ }^{1,8,9}$

Anak yang menderita RM termasuk anak dengan kebutuhan khusus. Anak dengan kebutuhan khusus mempunyai hak yang sama dengan anak normal lainnya untuk mendapatkan pelayanan kesehatan yang optimal. ${ }^{1,8,9}$
Penatalaksanaan tindakan perawatan gigi pada anak dengan kondisi retardasi mental secara umum sama dengan anak normal, tetapi memerlukan pendekatan secara multidisiplin dan individual dan tergantung pada derajat RM serta kelainan yang menyertainya seperti pada kasus ini, pasien RM yang disertai dengan cerebral palsy. Sebagian besar anak RM yang disertai dengan kelainan berbagai organ (sindroma) seperti jantung, paru-paru, kelemahan otot-otot (CP) sehingga memerlukan penanganan dan persiapan lebih intensif. Seperti misalnya pada anak cerebral palsy yang mempunyai refleks muntah dan sensitifitas yang tinggi pada rongga mulutnya. ${ }^{1,8,9}$

Persiapan mental memerlukan perhatian khusus pada anak RM. Penjelasan mengenai tindakan yang akan diberikan pada penderita RM serta keluhan yang akan muncul perlu dijelaskan sebelumnya pada keluarga pasien, mengingat pasien dengan RM sering disertai perilaku yang agresif atau sebaliknya. ${ }^{1,8,9}$

Penanganan pada penderita retardasi mental meliputi pengenalan terhadap pasien dan keluarga kepada dokter gigi dan staf, berbicara dengan pelan dan gunakan istilah yang mudah dipahami, memberikan instruksi satu persatu, sambil memberikan pujian dan hadiah, menciptakan komunikasi yang baik antara dokter gigi dan pasien, orang tua sebaiknya mendampingi anaknya ke tempat praktik, pertemuan sesingkat mungkin, melakukan prosedur yang sulit secara perlahan-lahan setelah pasien terbiasa dengan lingkungan.tempat praktik dokter gigi, dan yang terakhir, hendaknya pasien dijadwalkan pada pagi hari saat dokter gigi, staf, dan pasien belum terlalu letih. $^{9,10}$

Suksesnya penanganan anak yang berkebutuhan khusus memerlukan pertimbangan tersendiri, termasuk penggunaaan teknik psikologis, teknik pengendalian fisik dan 
pendekatan farmakoterapeutik. Akan tetapi hal ini juga tergantung dari kondisi serta derajat kelainan yang diderita., ${ }^{2,3}$

Untuk itu dalam makalah ini akan dibahas mengenai pengembalian fungsi pengunyahan seorang pasien dengan kebutuhan khusus (cerebral palsy yang disertai retardasi mental) akibat kehilangan gigi anterior yang ditangani dengan pembuatan gigitiruan kerangka logam

\section{LAPORAN KASUS}

Seorang pasien laki-laki, umur 17 tahun dengan kelainan cerebral palsy yang disertai dengan mild mental retardation datang ke Klinik Gigi dan Mulut YPAC Jakarta. Pasien ingin dibuatkan gigi palsu karena keluhan fungsi pengunyahan serta gangguan penampilan yang menyebabkan kurangnya rasa percaya diri pasien. Pada pemeriksaan klinis intra oral, nampak kehilangan gigi 41 sampai 45, serta linger alveolar yang sudah hilang akibat kehilangan gigi yang terlalu lama.

Keadaan umum pasien cukup baik. Pasien datang menggunakan kursi roda. Pasien tidak dapat berjalan karena terasa lemah di tungkai bawah, kedua lengan sering kaku sehingga sulit memegang suatu benda. Komunikasi dapat dilakukan dengan lancer dan jelas.

\section{Pemeriksaan intra oral}

Pada pemeriksaan intra oral didapatkan karies superfisial pada gigi 16, 26, 36, dan 46. Malposisi gigi berupa rotasi pada gigi 11, 12, 21,22, 14, 24, 33, dan 34. Kebersihan mulut sedang. Lidah, gingiva, mukosa, dan tonsil normal. Garis median rahang atas dan rahang bawah bergeser ke kanan. Ditemukan adanya diastema pada gigi 11, 12, 21, dan 22. Edentulus pada regio 41, 42, 43, 44, dan 45 .

\section{Kunjungan pertama}

Pada kunjungan pertama dilakukan anamnesis dan pemeriksaan klinis, serta pencetakan rahang atas dan rahang bawah.

Pada saat datang pasien didampingi oleh orang tua sehingga komunikasi dapat dilakukan dari pihak orang tua dan pasien ini sendiri. Dari anamnesis didapatkan data riwayat bahwa pasien telah kehilangan giginya 41, 42, 43, 44, dan 45 sejak tiga tahun yang lalu akibat kecelakaan motor, dan pada pemeriksaan klinis tampak lingir alveolar yang sudah menyusut.

Untuk rencana terapi pada kehilangan gigi anterior, kami mengarahkan untuk pembuatan gigitiruan dengan kerangka logam dengan pertimbangan kondisi lingir pasien yang sudah hilang, serta dapat memberi kemudahan dalam proses pembuatan, insersi dan pemakaiannya. Setelah rencana perawatan disetujui oleh pasien maka dilakukan pencetakan rahang atas dan rahang bawah untuk pembuatan model studi dan model kerja, kemudian tindakan penambalan pada gigi yang mengalami karies serta pembersihan karang gigi untuk gigi rahang atas dan rahang bawah.

\section{Kunjungan kedua}

Pada kunjungan kedua, kerangka logam yang dibuat oleh laboran dental dicobakan pada pasien untuk melihat penyesuaian lingirnya dengan gigi alami dan jaringan lunak sekitarnya (gambar 1,2). Selanjutnya dipasang wax gigitan untuk penyesuaian dan penyusunan gigi artifisial pada bahan kerangka logam tersebut (gambar 3). Setelah itu kerangka logam dan galengan gigit dipasang kembali pada model kerja pada posisi oklusi kemudian dikirim kembali ke laboran dental untuk penyusunan gigi artifisialnya (gambar 4). 


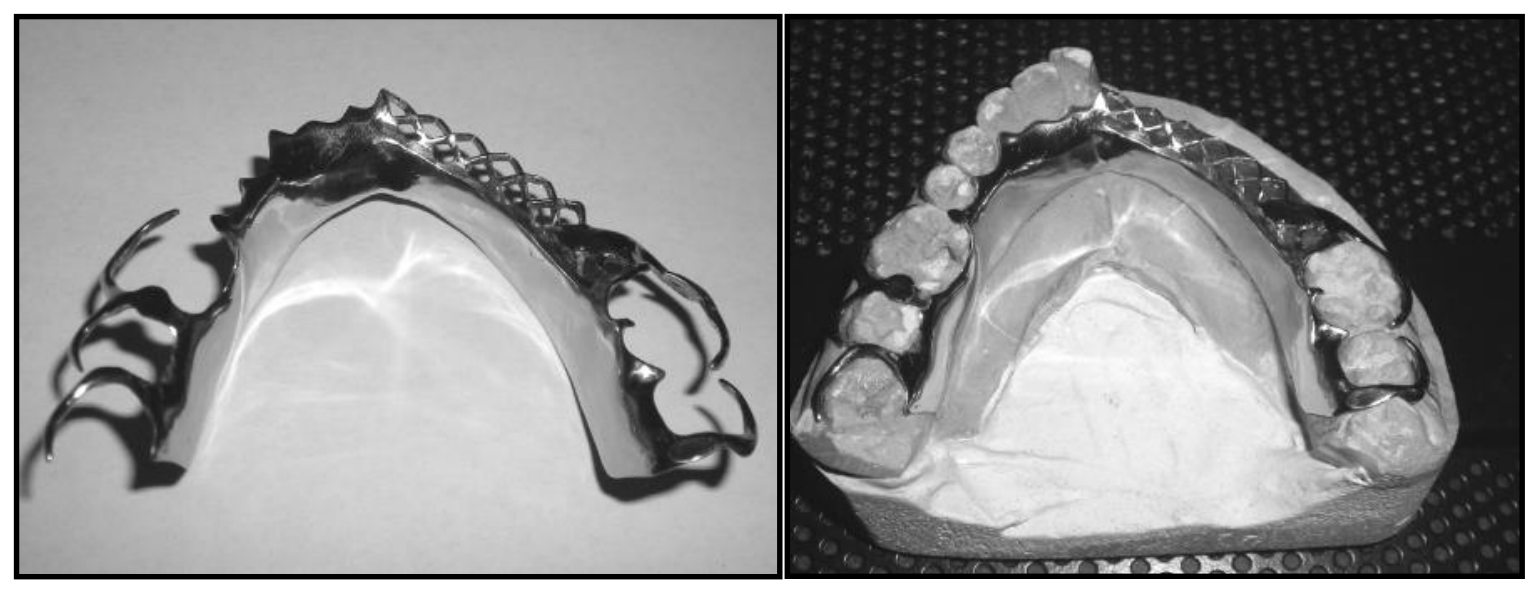

Gambar 1. Kerangka gigitiruan dari bahan metal

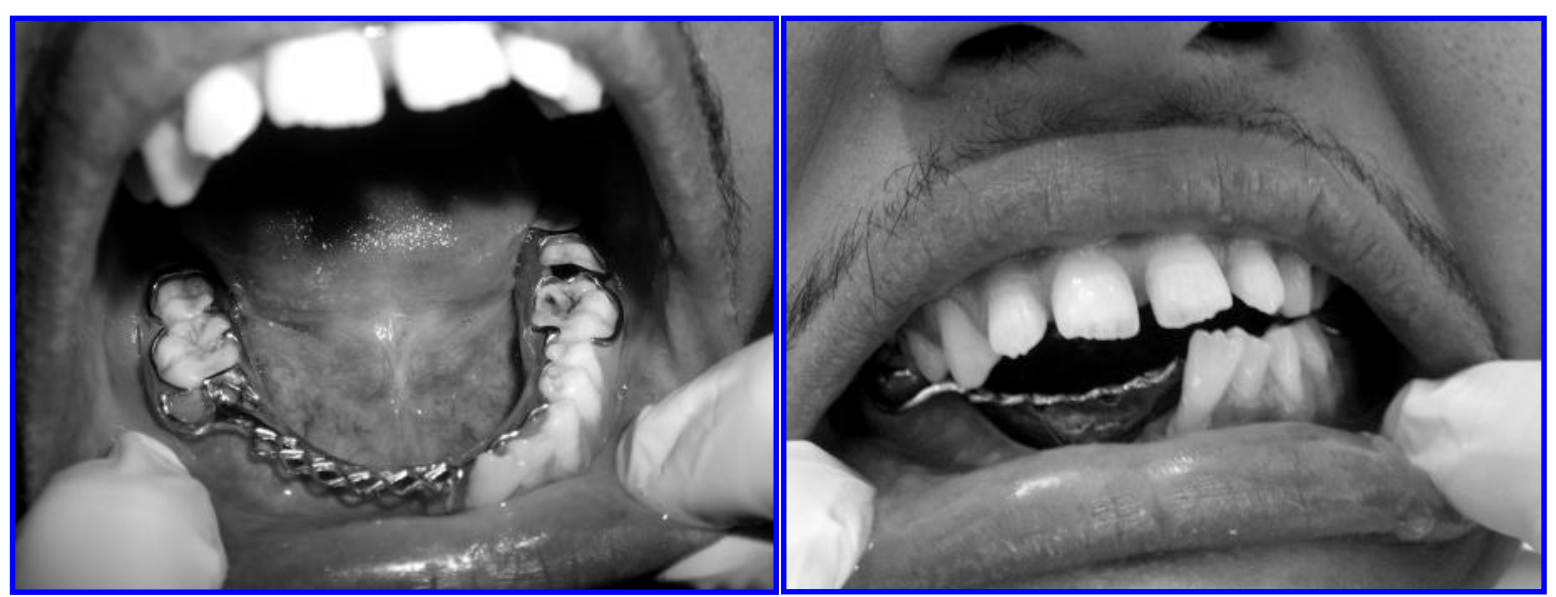

Gambar 2. Penyesuaian kerangka logam pada rongga mulut pasien

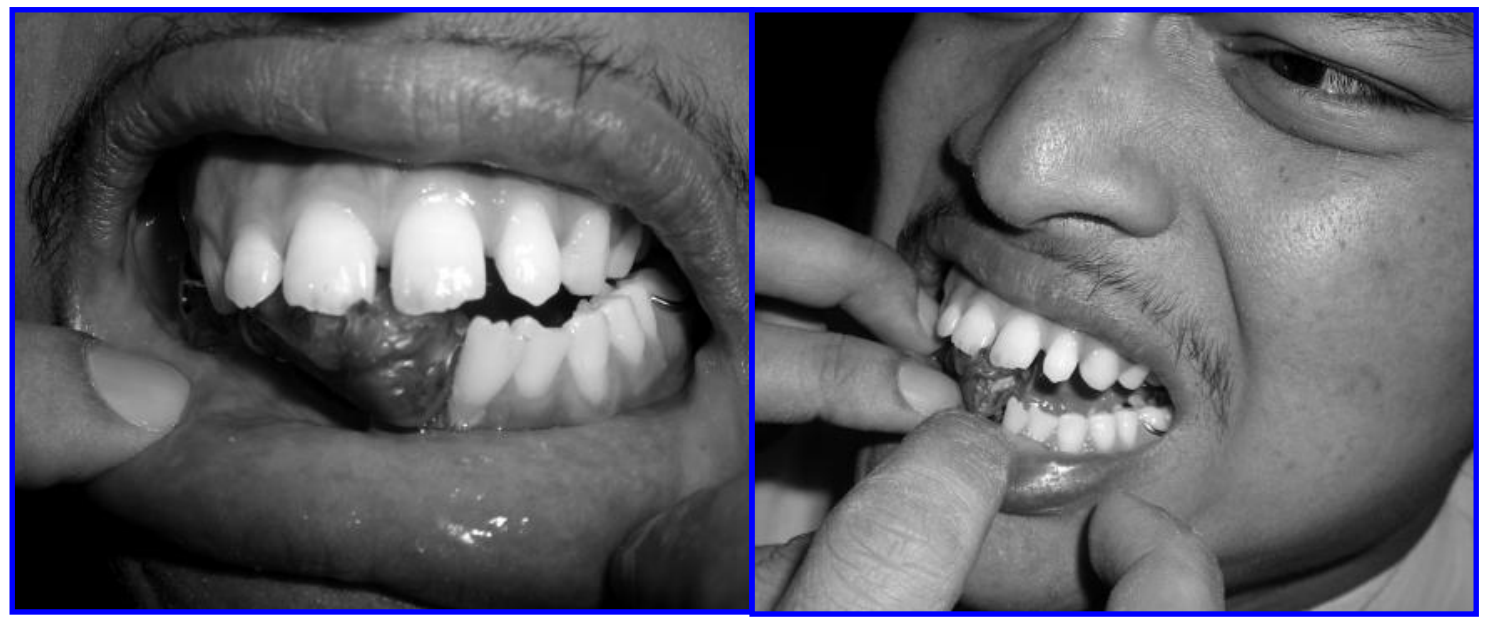

Gambar 3. Penyesuaian oklusi dan penentuan gigitan dengan menggunakan bahan wax 


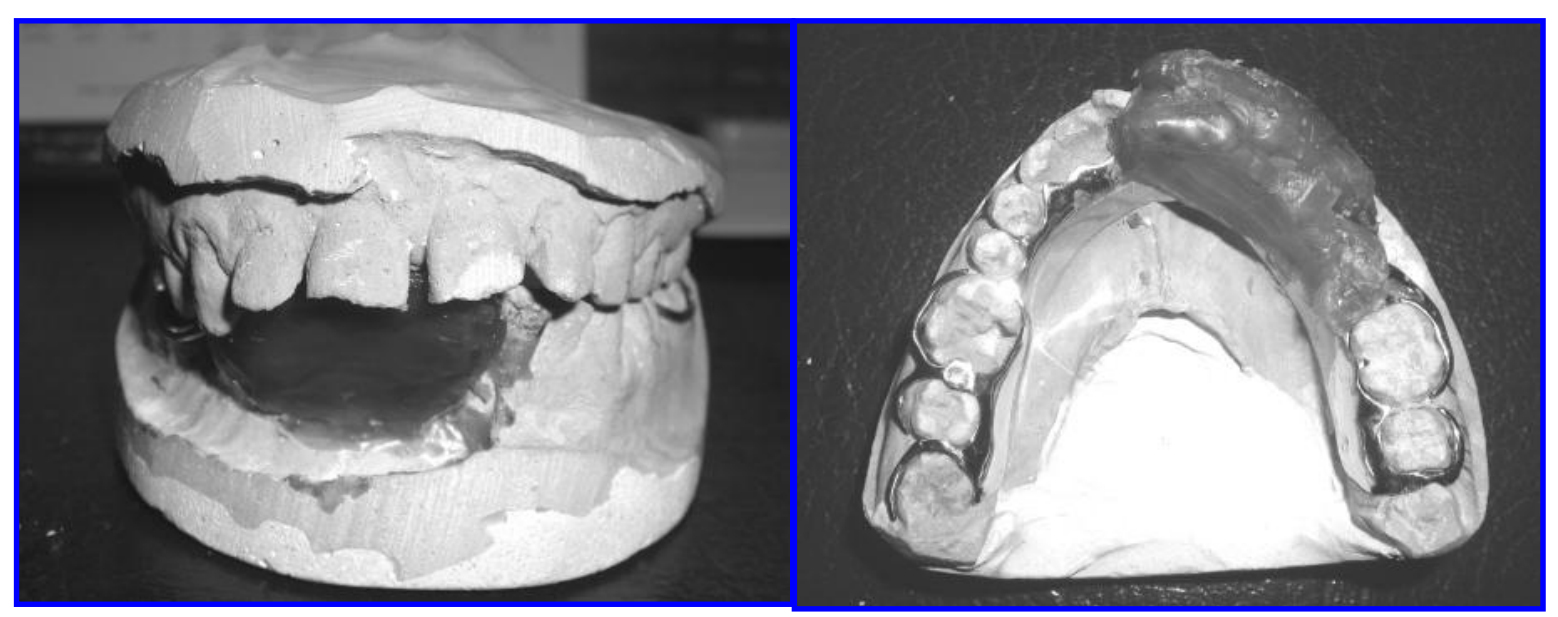

Gambar 4. Kerangka logam dan galengan gigit pada model kerja pasien

\section{Kunjungan ketiga}

Pada kunjungan berikutnya, gigitiruan kerangka logam yang telah jadi (gambar 5) dicobakan pada pasien, kemudian dilihat kondisi jaringan sekitarnya serta keluhan yang dirasakan pasien (gambar 6). Pada tahap ini pasien diinstruksikan untuk melakukan gerakan membuka dan menutup mulut serta gerakan ke lateral untuk melihat adanya keluhan pada saat pengunyahan. Pada saat yang sama, posisi relasi sentrik dan oklusi sentrik pada pasien dievaluasi. Setelah insersi percobaan kerangka logamnya pada tahap ini, dan pasien tidak merasakan adanya keluhan lagi, pasien diinstruksikan untuk datang lagi pada minggu berikutnya untuk dilakukan kontrol pada fungsi pemakaian gigitiruan, khususnya pada fungsi pengunyahan dan kemungkinan adanya kelainan fungsi sendi rahang yang telah dikeluhkan pasien sebelum insersi gigitiruan kerangka logamnya.

\section{Kontrol gigitiruan kerangka logam}

Pada tahap kontrol setelah pemakaian gigitiruan kerangka logam oleh pasien selama seminggu, pasien datang dengan ekpresi yang menyenangkan (gambar 7). Dari penjelasan pasien selama pemakaian tersebut dirasakan tidak ada lagi keluhan estetis serta dapat dipakai dalam fungsi pengunyahan khususnya pada pemakaian fungsi gigi geligi depan. Begitu pula pada kontrol 3 minggu berikutnya, keluhan sebelumnya pada daerah sendi rahang sudah agak berkurang dan memberi efek menyenangkan pada fungsi pengunyahan pasien.

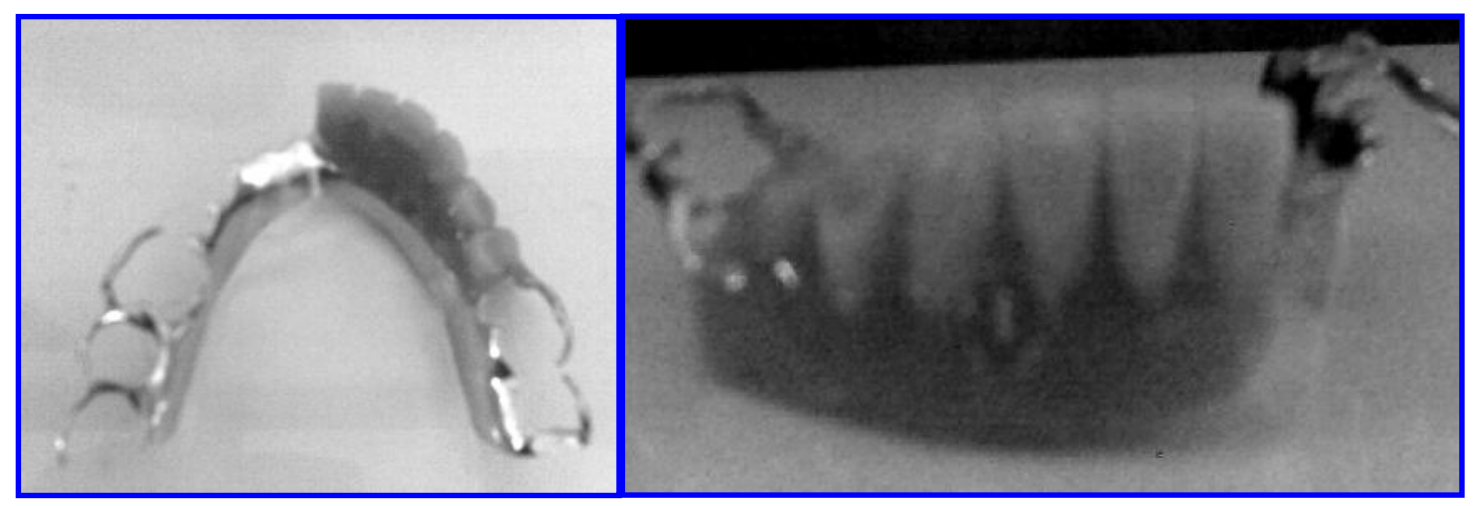

Gambar 5. Gigitiruan kerangka logam 

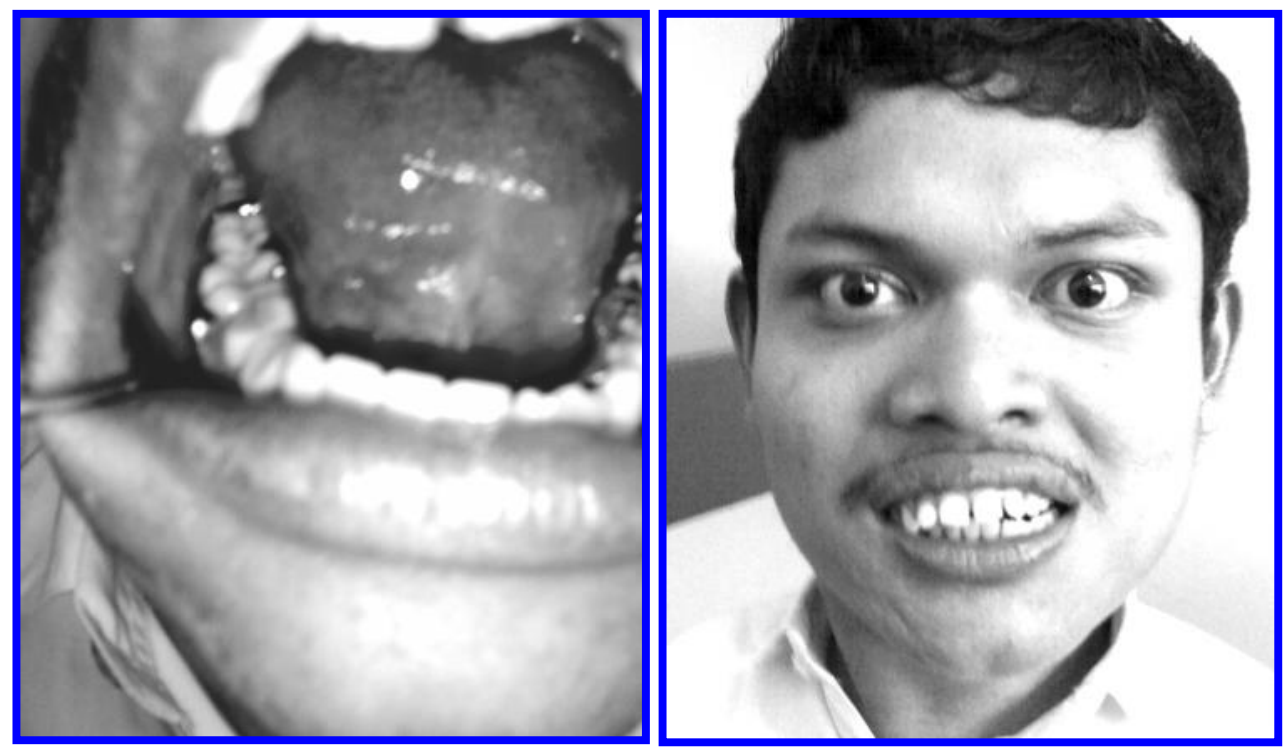

Gambar 6. Penyesuaian oklusi gigitiruan kerangka logam pada pasien

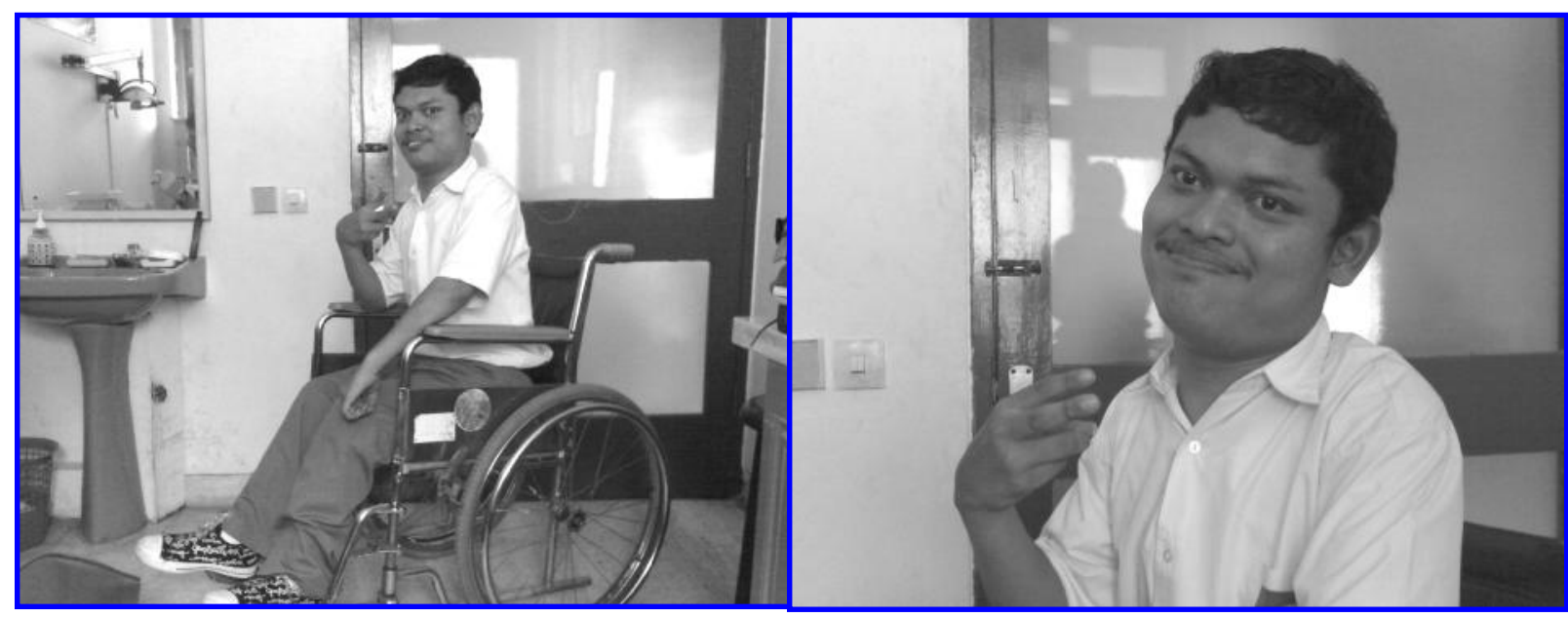

Gambar 7. Tampak ekspresi pasien yang menyenangkan pada tahap kontrol

\section{PEMBAHASAN}

Perawatan gigi bagi penderita anak yang berkebutuhan khusus telah lama diabaikan dan hanya sedikit dokter gigi yang merasa tertantang untuk dapat menanganinya. Perawatan gigi penderita anak yang berkebutuhan khusus sebenarnya tidak banyak berbeda dari pasien yang normal, tetapi ketentuan tatalaksana tindakan biasanya lebih sulit dan memerlukan kesabaran. Kebutuhan perawatan gigi penderita anak yang berkebutuhan khusus pada umumnya dapat dicapai melalui cara yang dipergunakan pada anak normal. Sebagian besar individu penderita mempunyai kebersihan mulut yang buruk dibandingkan dengan anak normal. ${ }^{2,4,5}$

Ada beberapa faktor yang perlu diperhatikan dan bisa menghambat penanganan perawatan pada penderita anak yang berkebutuhan khusus, yaitu kurangnya kerjasama dari pihak keluarga pasien, rasa enggan, malu, dan depresi dari keluarga untuk memperlihatkan anak di depan umum, kurang menghargai dan menerima perawatan gigi, kurang pengertian, apresiasi, dan kesadaran karena menganggap penyakit gigi tidak membahayakan keselamatan hidup, membutuhkan perlengkapan khusus yang relatif mahal, kurang mobilisasi, 
biaya perawatan gigi yang relatif besar, dan letak tempat praktik yang kurangn memadai.

Secara umum retardasi mental diklasifikasikan menurut skor intelligence quotient (IQ) yang diperoleh dari tes inteligensia. American Association of Mental Deficiency (AAMD) mengklasifikasikan taraf inteligensi anak retardasi mental menjadi empat kategori, yaitu retardasi mental ringan (mild) dengan skor IQ 69-55 adalah anak yang mampu didik sehingga mereka cukup mampu berkomunikasi dan berbicara; anak retardasi sedang (moderate) dengan skor 54-40 dapat dilatih atau mampu latih tetapi komunikasi hanya terbatas pada tingkat dasar; retardasi mental berat (severe) dengan skor 39-25 menjadikan anak sulit dilatih dan sulit berkomunikasi; dan retardasi sangat berat (profound) dengan skor IQ kurang dari 25 adalah anak tidak dapat dilatih dan juga tidak dapat berkomunikasi. ${ }^{1,3}$

Pada kasus ini pasien yang mengalami kelainan cerebral palsy yang disertai dengan mild mental retardation, di samping bantuan komunikasi dari orang tua, pasien yang bersangkutan juga masih dapat diajak untuk berkomunikasi meskipun dengan cara yang sangat sederhana oleh karena kemampuan pasien dalam menangkap dan menyampaikan informasi masih agak sulit.

Dari awal kunjungan hingga selesainya proses perawatan yang dilakukan pasien cukup koperatif dalam menerima setiap instruksi dan tindakan. Hal ini mungkin juga disebabkan oleh kemauan pasien yang kuat dalam memperbaiki tampilan serta meningkatkan percaya diri pasien dengan kondisi umur yang sudah remaja. Adapun kendala yang didapatkan pada penanganan pasien ini selama tindakan adalah kesulitan pada saat pencetakan gigi geligi karena refleks muntah yang tinggi.
Pada pasien ini juga didapatkan kemampuan sosialisasi dan proses adaptasi dengan lingkungannya cukup baik. Hal ini terlihat dari hubungan interpersonal dengan lingkungan sekitarnya. Hal ini mungkin dipengaruhi oleh faktor pendidikan yang diterima serta kesempatan sosial dalam berinteraksi dengan lingkungan yang cukup kondusif.

\section{SIMPULAN}

Dari pembahasan mengenai pengembalian fungsi pengunyahan pada anak dengan kelainan cerebral palsy dan mild dental retardation, disimpulkan bahwa perencanaan perawatan gigi bagi penderita anak yang berkebutuhan khusus adalah untuk tercapainya keseluruhan perawatan dan pencegahan terhadap penyakit giginya, dengan demikian perlu pula mempelajari permasalahan yang terdapat di masyarakat dan lingkungannya.

Mempertahankan kesehatan gigi dan mulut anak yang berkebutuhan khusus secara menyeluruh adalah sangat penting. Pencegahan dan perawatan bukan hanya ditujukan terhadap karies dan penyakit periodontalnya, melainkan keadaan maloklusi seperti kehilangan satu atau lebih gigi dalam waktu yang cukup lama perlu juga mendapat perhatian, sehingga pada akhirnya dapat dicapai fungsi pengunyahan maupun fungsi estetik secara optimal.

Meskipun pada dasarnya, anak dengan kebutuhan khusus perlu melibatkan orang tuanya untuk proses komunikasi dan pendekatan psikologis, namun pada beberapa kondisi anak dengan retardasi mental derajat ringan dan sedang masih mungkin dididik dan mampu dilatih. Oleh karena itu pendidikan kesehatan gigi perlu diberikan kepada mereka dengan cara yang lebih sederhana dan mudah dimengerti. 


\section{SARAN}

Mengingat prevalensi yang lebih tinggi terjadinya penyakit gigi dan mulut pada pasien dengan kebutuhan khusus dibandingkan dengan anak normal, maka perlu ditekankan pada orang tua pasien untuk lebih intensif memeriksakan giginya secara teratur. Penting pula mengingatkan bagi orang tua untuk senantiasa melakukan pendekatan pada anak dengan kehangatan, kasih sayang, dan kesabaran yang tinggi, sehingga anak dapat menikmati perawatan dengan rasa aman.

\section{DAFTAR PUSTAKA}

1. Suharsini M. Perawatan gigi dan mulut pada anak retardasi mental. Jurnal Kedokteran Gigi Fakultas Kedokteran Gigi Universitas Indonesia 2000; :189-94.

2. Rosenbaun P. The defenition and classification of cerebral palsy: are we any further ahead in 2006? Neoreviews [online] 2006. Availalble at: http://neoreviews. appublications.org/cgi/reprint/neoreviews; $7 / 1$ 1/e569.pdf. Diakses: 20 Januari 2007.

3. Stanford Jr, Thomas W. Cerebral palsy and dentistry: a brief review [online] 2000. Available http://www.geocities.com/aneecp/dental.htm. Diakses: 14 Januari 2007.

4. Sutadi H. Masalah perawatan gigi dan mulut anak penderita cerebral palsy. Jurnal kedokteran Gigi Fakultas Kedokteran Gigi Universitas Indonesia 1995; :.40-8.

5. Wikipedia. Cerebral palsy. [online] 2007. Available at: http://en.wikipedia.org/wiki/cerebralpalsy. Diakses: 19 Februari 2007.

6. Stewart RE, Barber TK, Troutman KC. Pediatric dentistry, scientific foundation and clinical practice. St Louis: Mosby Co.; 1982. p. 158, 834-6.

7. Law DB, Lewis TH, Davis JM. The handicapped child in an atlas of pedodontics. Philadelphia: W.B. Saunders Company; .p. 307-8.

8. Levine N. Dental caries treatment for the disabled person in current treatment in dental practice. Philadelphia: W.B. Saunders Company; 1986. p. 381-8.

9. Noerdin S. Masalah penanganan perawatan gigi pada penderita cacat. Jurnal Kedokteran Gigi Fakultas Kedokteran Gigi Universitas Indonesia 1999; 6 (1): Jakarta: 36-41.

10. McDonald RE, Very DR. Dental problems of the disabled child in dentistry for the child and adolescent, $6^{\text {th }}$ ed. St. Louis: Mosby Company; 1994. p. 592-61 